\title{
The Age of Discrimination: Race and American Foreign Policy after World War I
}

\author{
Michael L. Krenn
}

check for

Citation: Krenn, Michael L. 2022. The Age of Discrimination: Race and American Foreign Policy after World War I. Genealogy 6: 16. https:// doi.org/10.3390/genealogy6010016

Received: 17 December 2021

Accepted: 3 February 2022

Published: 14 February 2022

Publisher's Note: MDPI stays neutral with regard to jurisdictional claims in published maps and institutional affiliations.

Copyright: (C) 2022 by the author. Licensee MDPI, Basel, Switzerland. This article is an open access article distributed under the terms and conditions of the Creative Commons Attribution (CC BY) license (https:// creativecommons.org/licenses/by/ $4.0 /)$.
Department of History, Appalachian State University, Boone, NC 28608, USA; krennml@appstate.edu

\begin{abstract}
The decade after World War I has traditionally been defined as an "age of isolation." The American public's disillusionment with World War I, highlighted by the dismal failure of President Woodrow Wilson's efforts to join the League of Nations, led to "A Return to Isolationism," according to a brief summary of American diplomacy produced by the Department of State. Despite the fact that historian William Appleman Williams attempted to destroy the "legend of isolationism in the 1920s" and other scholars have followed his lead with a string of publications recounting the very active U.S. engagement with the rest of the world following the war, many textbooks continue to describe the 1920s as an age wherein the United States withdrew into a shell of isolation. My article suggests that one way of reconciling these apparently contradictory interpretations of American foreign policy in the decade after World War I is to examine one particular factor that has been largely overlooked: Whether "isolationist" or not, the United States during those years utilized race as a way to simultaneously build walls in and around the American nation as well as construct the ideological foundations for U.S. postwar expansion and engagement.
\end{abstract}

Keywords: race; U.S. foreign policy; 1920s

\section{Introduction: Racism at Home, Racism Abroad}

The decade after World War I has traditionally been defined by historians of U.S. foreign relations as an "age of isolation". The American public's disillusionment with World War I, highlighted by the dismissal of President Woodrow Wilson's efforts to have the United States join the League of Nations, led to "A Return to Isolationism", according to a brief summary of American diplomacy produced by the Department of State. Despite emerging from the war as a political, economic, and military force in the world, "the nation was not yet ready to accept responsibilities commensurate with its power" (See Office of the Historian, U.S. Department of State 2021). Despite the fact that historian William Appleman Williams attempted to destroy the "legend of isolationism in the 1920s" and other scholars have followed his lead with a string of publications recounting the very active U.S. engagement with the rest of the world following the war, many American history textbooks continue to describe the 1920s as an age wherein the United States simply withdrew into a shell of isolation. ${ }^{1}$ One way of reconciling these apparently contradictory interpretations of American foreign policy in the decade after World War I is to examine one particular factor that has been largely overlooked: whether "isolationist" or not, the United States during those years utilized race as a way to simultaneously build walls in and around the American nation as well as construct the ideological foundations for U.S. postwar expansion and engagement with people of color around the globe. Indeed, understanding the ways in which race was used in postwar America to cement the walls of Jim Crow segregation and construct new barriers to the entry of "undesirable" and "inferior" foreigners is absolutely vital in terms of grasping the meaning and intent of the nation's foreign policy during that same time period. U.S. foreign policymakers took the new and virulent forms of domestic racism, combined them with their pre-existing views of "inferior" races around the globe, and created one of the touchstones for the construction 
of American power and influence during the decade following World War I. Two of the most important and popular spokesmen for eugenics, racial segregation, and restricted immigration, Madison Grant and Lothrop Stoddard, led the way in putting America's domestic race issues into a global context, writing extremely well-received books on the struggle the white race faced in dealing with the "inferior" races around the world. U.S. policymakers followed suit, with Woodrow Wilson crushing the Japanese resolution for international racial equality at the Versailles Peace Conference and other U.S. officials casting a dubious eye on Latin American efforts at self-government by utilizing the very same racist stereotypes they employed in discussing the African American struggle for equality at home and the necessity of closing the door to "undesirable" immigrants. In these, and many other ways, the U.S. government used the post-World War I decade as a testing ground for theories of white supremacy, the inferiority of people of color around the world, and the proper place of the United States in the postwar international arena.

\section{The Domestic Context}

While the main focus of this essay is how the United States used race as a fundamental part of its diplomatic policies and initiatives in the decade after the war, a brief summary of how racism functioned at home during that time is useful for understanding how closely domestic and international views on racial and ethnic differences coincided in building a clear consensus on how "superior" races needed to construct new approaches and instruments for maintaining their power over the "inferior" races. Although the 1920s are often portrayed in popular culture as a time of wild new dances, bathtub gin, wisecracking gangsters, movie and sports celebrities, and unbridled materialism, it was also a time of intense bigotry, discrimination, and violence toward those who were deemed "undesirable". For African Americans, it was a particularly painful period when thousands of black veterans returned home only to face the onslaught of what came to be known as the "Red Summer". Fueled in some areas by resentment over the hundreds of thousands of African Americans who migrated north and west during the war seeking employment, and in some by the general lunacy of the "Red Scare" that portrayed any sort of protest or difference as somehow communistic and "un-American", whites turned their anger, frustration, and unease against black citizens. Across America, in both urban and rural areas, violent assaults by angry mobs of white Americans resulted in the destruction of hundreds of thousands of USD worth of property and deaths that ranged from nearly fifty people in Chicago, to estimates of over two-hundred African Americans murdered in Elaine, Arkansas. ${ }^{2}$

At the same time that many white Americans were pushing back against the demands for more political and economic power from the African American population, others were determined to ensure that the numbers of other racial and ethnic "undesirables" in the United States remained as low as possible. One answer was to limit the reproduction of people designated as inferior through the application of the new theories of eugenics that were growing among many U.S. intellectuals. In brief, the theories posited that everything should be done to make sure that the "best" blood lines continued on (such as encouraging hardy Anglo-Americans to have more children) and by stopping the reproductive capacity of those deemed less than desirable through policies of forced sterilization. Yet, what about the masses of immigrants who fell into the "less desirable" categories gathering at America's gates? The solution arrived at was to simply keep such people from coming to the United States in the first place. The result of such thinking was the highly restrictive immigration law passed by Congress in 1924, which limited new immigration into America to 150,000 people a year and set strict quotas: immigration from any nation would be limited to two percent of the people from those nations residing in the United States in 1890. Little wonder that eugenics and immigration restriction often worked hand in hand. A report to the United States Committee on Selective Immigration from a group of leading eugenicists left no doubt about the purpose of such restrictive legislation. It would "change the character of immigration, and hence of our future population, by bringing about a 
preponderance of immigration of the stock which originally settled this country". The quotas ensured this: By 1929, over 120,000 of the 150,000 immigrants allowed into America were to be from western and northern Europe. ${ }^{3}$

This very brief summary of the development of racist philosophies and laws in the United States is a necessary prelude to deconstructing the myth of the 1920s as an "age of isolation" in terms of the nation's foreign policy. At least initially, what has just been described might be seen as bolstering that myth — the United States turning inward, punishing those who were different and excluding those seen as not meeting the high racial standards of white America. This, however, was very far from the case. Just as the United States was busy constructing the walls of racial discrimination and white superiority at home through racist violence, anti-immigration legislation, and eugenics, it was also turning its attention to repairing and buttressing the walls of white dominance abroad. Those barriers between the white colonialist and imperialist nations and the hordes of people of color in Africa, Asia, and Latin America seemed to be under attack as never before. Before those walls could be breached, U.S. officials redoubled their efforts by constructing a new and more sophisticated racist ideology to stem the tide of change.

\section{Confronting the Japanese}

Their first opportunity came quickly after the end of World War I. As representatives of the nations that worked together to defeat Germany and its allies during the conflict met at Versailles outside of Paris in 1919 to hammer out a peace settlement, the delegations from the United States and the colonial superpower Great Britain found themselves confronted with a nasty and unexpected surprise. In the midst of the debates about reparations, disarmament of the defeated enemies, and redrawing the lines of control in Europe and around the colonized world, the Japanese representatives put forward a resolution dealing with race. The proposal was deceptively simple, stating that, "The equality of nations being a basic principle of the League of Nations, the High Contracting Parties agree to accord as soon as possible to all alien nationals of states, members of the League, equal and just treatment in every respect making no distinction, either in law or in fact, on account of their race or nationality". However, the introduction to the proposal, made by one of the most important figures of the Japanese delegation, suggested the potentially far-reaching goals:

Prejudices had been a source of troubles and wars throughout history and they may become more acute in the future. The problem possessed a very delicate and complicated nature involving the play of human passions, but equality could not be denied simply because of one's race. Shared struggles during the war demonstrated that different races worked with each other, saving lives irrespective of racial differences, and a common bond of sympathy and gratitude had been established to an extent never before experienced. I think it only just that after this common suffering and deliverance the principle of equality among men should be admitted ... For these several reasons, political and moral integrity required the delegates to go on record supporting the following amendment (Lauren 1978).

The Japanese were to be sorely disappointed, however. The U.S. delegation was led by President Woodrow Wilson, whose racist views were already well-established. In 1914, Wilson met with a group of African American spokespersons to discuss their dismay over his policies, such as the segregation of federal offices in Washington, D.C., which had been one of the new President's first actions. Wilson responded with classic paternalism, informing the delegates that:

The white people of the country, as well as I, wish to see the colored people progress, and admire the progress they have already made, and want to see them continue along independent lines. There is, however, a great prejudice against colored people ... It will take one hundred years to eradicate this prejudice, and we must deal with it as practical men. Segregation is not humiliating, but a 
benefit, and ought to be so regarded by you gentlemen. If your organization goes out and tells the colored people of the country that it is a humiliation, they will so regard it, but if you do not tell them so, and regard it rather as a benefit, they will regard it the same. The only harm that will come will be if you cause them to think it is a humiliation.

When Monroe Trotter, one of the African American attendees at the meeting, noted that Wilson was overturning nearly fifty years of policy, the President brusquely replied, "If this organization is ever to have another hearing before me it must have another spokesman. Your manner offends me ... . Your tone, with its background of passion". ${ }^{4}$

When the Japanese resolution was put to a vote, it secured a clear majority, with eleven of the seventeen delegates in attendance voting yes. Wilson, who was chairing the peace conference proceedings, unilaterally declared that, due to the "serious objections" on the part of some of the attendees, a unanimous vote would be needed and therefore declared that the motion failed. What Wilson meant, of course, was that the United States (which, considering its miserable record of treatment of its African American citizens could hardly be counted on to support racial equality) and the British (who feared how such a resolution might ring in the ears of the millions of people of color held under their colonial bondage) would not support the Japanese proposal. ${ }^{5}$

Wilson's own engrained racism was partially responsible for sinking the Japanese resolution, but anyone keeping an eye on American thinking about race and power in the international sphere would have known that the Japanese proposal was doomed from the start. In the years during and just after World War I, a number of American intellectualsmany of whom were already intensely interested in the racial and ethnic issues facing the U.S. at home-turned their attention to the wider world. One of the most important of these thinkers was Madison Grant. A Yale graduate who received his law degree from Columbia, Grant soon became involved with the growing eugenics movement in America and was an active and influential figure in the anti-immigration movement that reached its height during the 1920s. His 1916 book, The Passing of the Great Race, went through several editions and sold well into the 1930s. Grant's basic premise was relatively simple: race was a determining factor in human progress, the growth of democracy, and the development of civilization. He further suggested that the Caucasian race was superior to all others, and that only where the white race dominated could the flowering of civilization take place. In particular, Grant singled out the "Nordic" race for its military prowess, dedication to democracy, and work ethic. He spewed forth his usual racist screeds about "race suicide" (the fear that lesser races were producing offspring at a faster rate than the Nordic peoples), eugenics, the necessity of forced sterilizations to remove "undesirables" from American society, and his desire for highly restrictive immigration legislation. Grant also suggested that the need to contain these "lesser" races was absolutely essential to the survival of the white race. As he noted, "Australia and New Zealand, where the natives have been virtually exterminated by the whites, are developing into communities of pure Nordic blood and will for that reason play a large part in the future history of the Pacific. The bitter opposition of the Australians and Californians to the admission of Chinese coolies and Japanese farmers is due primarily to a blind but absolutely justified determination to keep those lands as white man's countries". Turning his attention to Africa, Grant declared that, "the density of the native population will prevent the establishment of any purely white communities, except at the southern extremity ... The stoppage of famines and wars and the abolition of the slave trade, while dictated by the noblest impulses of humanity, are suicidal to the white man. Upon the removal of these natural checks Negroes multiply so rapidly that there will not be standing room on the continent for white men ... " (Grant 1936). 


\section{The Ideological Foundations of American Racism}

Just a few years later, Lothrop Stoddard-staunch supporter of eugenics and antiimmigration laws-took Grant's ideas a step farther. Armed with a Ph.D. in history from Harvard, Stoddard focused his 1920 book, The Rising Tide of Color: The Threat Against White World Supremacy, on the dangers posed by the hordes of people of color around the globe. Its rather lurid title perhaps accounted for the book being even more popular than Grant's earlier work. After providing a rough racial census of the planet, Stoddard concluded, "Such is the ethnic make-up of that world of color which, as already seen, outnumbers the white world two to one. That is a formidable ratio, and its significance is heightened by the fact that this ratio seems destined to shift still further in favor of color. There can be no doubt that at present the colored races are increasing very much faster than the white". While the white population in the United States and western Europe was slowing in its reproductive rate, "none of the colored races shows perceptible signs of declining birth-rate, all tending to breed up to the limits of available subsistence. Such checks as now limit the increase of colored populations are wholly external, like famine, disease, and tribal warfare". The "irony of fate", according to Stoddard, was that "The greater part of the colored world is to-day under white political control. Wherever the white man goes he attempts to impose the bases of his ordered civilization". Admirable as this might seem, it was actually leading to a rapid increase in the "native" populations of Asia, Africa, and Latin America. This was a recipe for disaster: "Now what must be the inevitable result of all this? It can mean only one thing: a tremendous and steadily augmenting outward thrust of surplus colored men from overcrowded colored homelands". One outcome would be that these races would try to push their way "into those emptier regions of the earth under white political control. But many of these relatively empty lands have been definitely set aside by the white man as his own special heritage. The upshot is that the rising flood of color finds itself walled in by white dikes debarring it from many a promised land which it would fain deluge with its dusky waves". In short, they would attempt to immigrate to the more "civilized" lands under the control of whites-unless, of course, strong anti-immigration laws were put into effect. Of particular concern to Stoddard were the "Asiatic" hordes. It was evident that, "the white world cannot permit this rising tide free scope. White men cannot, under peril of their very race-existence, allow wholesale Asiatic immigration into white race-areas".

For Stoddard, however, the threat to America went beyond Asian immigration to U.S. shores. There was much more at stake:

But the matter does not end there. The white world also cannot permit with safety to itself wholesale Asiatic penetration of non-Asiatic colored regions like black Africa and tropical Latin America. To permit Asiatic colonization and ultimate control of these vast territories with their incalculable resources would be to overturn in favor of Asia the political, the economic, and eventually the racial balance of power in the world. At present the white man controls these regions. And he must stand fast. No other course is possible. Neither black Africa nor mongrel-ruled tropical America can stand alone. If the white man goes, the Asiatic comes-browns to Africa, yellows to Latin America. And there is no reason under heaven why we whites should deliberately present Asia with the richest regions of the tropics, to our own impoverishment and probable undoing. Our race-duty is therefore clear. We must resolutely oppose both Asiatic permeation of white race-areas and Asiatic inundation of those non-white, but equally non-Asiatic, regions inhabited by the really inferior races (Stoddard 1921).

\section{Containing Latin America}

As Stoddard made clear, one of the main areas of concern was Latin America to which, he believed, the "yellows" would flow if barred from entry into the United States and other white areas. It was America's "race-duty" to keep such "regions inhabited by the really inferior races" safe under the protection and guidance of the United States. Unfortunately, 
during the post-World War I period the United States faced serious challenges to its economic and political goals in that region. The relationship in the years before the U.S. entry into World War I had been fraught with tension and animosity. The Roosevelt Corollary, the construction of the Panama Canal, and U.S. military interventions in various nations created an atmosphere of resentment and anti-American sentiments throughout Latin America. All of this climaxed during the Wilson years, during which the U.S. leader informed a reporter than he was going to "teach the South American republics to elect good men". For those who did not wish to imbibe the lessons of U.S. democracy, Wilson unleashed military occupations of Haiti and the Dominican Republic and sent U.S. troops into Mexico twice. By the end of World War I, many Latin American nations were seething with anger at (and fear of) the "colossus of the North", and sought ways to assert their economic and political independence from Washington. ${ }^{6}$

This was in full display at the 1919 peace conference at Versailles. As one U.S. official at the conference observed, the Latin American attendees "have been left alone too much and have been having Latin American conferences among themselves". This was a situation that would need to be addressed so as to encourage them to "give us their entire support". However, things went from bad to worse, and the U.S. was having a "very difficult time with the Latin Americans" who sought equal representation on many of the important conference commissions, in particular the Financial and Economic Commission". When the Latin American nations were given only limited participation, this resulted in a "storm against the Great Powers". The U.S. official concluded on an ominous note: "A tempest in a teapot, you may say, but I for one think tea leaves are rather bitter and do not want the U.S. to have to drink any".

In this climate, U.S. officials during the 1920s took old racial views of Latin Americans as racially inferior "mongrels" (the commonly used term to describe the racial mixing of Spanish, African, and Native American blood among the people of the region) and began the construction of a new racist ideology to confront the challenges to U.S. hegemony posed by a more assertive Latin America. U.S. perceptions of Mexico and its people provide a telling example of this new ideology at work. Mexico was viewed as a particularly troublesome nation by American officials. Its revolutionary politics threatened U.S. trade and investments, especially in terms of the vast American oil holdings which the Mexican government now threatened with expropriation. As the U.S. ambassador to Mexico put it just months before the end of World War I, Mexican President Venustiano Carranza sought "the least connection possible between Mexico and the United States... His official newspaper is preaching economic, financial, diplomatic - every sort of independence of the United States. The so-called Carranza doctrine is to replace the Monroe Doctrine [and] the hegemony of the United States on this Continent is to pass away". 8

At least initially, the U.S. response tended to mimic the older and more vicious racist tropes. Efforts to deal with the Mexican leaders revealed the "futility of attempting to treat with a Latin-Indian mind, filled with hatred of our United States government". The Mexicans were "ignorant", "unwise", and "untrustworthy", and their leaders were even worse, such as Plutarco Calles (who would become the president of Mexico in 1924), the "dark man in the woodpile who will probably be the next trouble maker in Mexico". Other U.S. officials were even more vehement in their racist attacks. U.S. Ambassador James Sheffield, soon after arriving in Mexico in 1925, made clear the essential problem he faced: "The main factors are greed, a wholly Mexican view of nationalism, and an Indian, not Latin, hatred of all peoples not on the reservation. There is little white blood in the Cabinet-that is it is very thin". A former State Department official echoed Sheffield's assessment, branding the Mexican people as "so ignorant and of such a low mental capacity that they are utterly unfitted for self-government", and were thus easily manipulated by the "unscrupulous and selfish half-breed Mexicans who are in control of the Government today". An American oil lobbyist dispensed with any notion that the U.S. government was dealing with human beings, declaring that "the situation is much like that of the relationship between a vicious 
animal and its trainer. If the trainer showed fear, the animal would attack him, but if he showed courage and force, the animal would submit". 9

Other Latin American nations and people came in for similar disparagement. The people of Colombia were marked by "woeful ignorance"; Brazilians were mostly illiterate and apathetic, and its government and leaders were lazy and prone to violence; Venezuelans were "indolent", suffering from equal doses of "political immaturity" and "racial inferiority". All of this might have been of little concern except for the fact that U.S. officials believed that these racially inferior nations and people were also important parts of an increasingly interdependent world economic system. A U.S. banking executive clearly explained the worldwide division of labor: "For food and manufacturing material man had already developed the producing power of the Temperate Zones, especially the Northern Temperate, and now he is demanding that the tropics shall perform their proper share of the task of supplying the food and manufacturing material required by the 1700 million people of the globe". ${ }^{10}$

Yet, exactly how to deal with this situation was a perplexing one for U.S. officials. In the wake of World War I, military interventions (although they did not completely disappear), particularly in the larger nations of Latin America, seemed unrealistic. Without the might of America's armed forces, however, how would the "indolent" and "racially inferior" masses of Latin America be convinced to take up their "proper share" of the world's economic work? For at least one prominent American, a possible answer to the racial dilemma facing the United States in Latin America would be found in his nation's own recent history of dealing with the end of slavery. Elihu Root, former secretary of state, former secretary of war, and Nobel Peace Prize winner, suggested in 1927 that it had been "probably premature" for the United States to recognize the independence of the Latin American republics. The people of those nations were "admittedly like children and unable to maintain the obligations which go with independence". It reminded Root of developments in his own country, where the granting of suffrage to the recently freed slaves had been "a dismal step, a terrible mistake, with most serious evils following". The solution in the United States had been the steady but terribly effective disenfranchisement of African Americans. For nations such as Mexico, where the people had "undertaken to govern themselves without quite having learned the hang of it", dictatorship provided an alternative to anarchy and chaos. Furthermore, fortunately, an example of how effective this might be was immediately at hand. Under the leadership of Benito Mussolini, Italy was witnessing a "revival of prosperity, contentment and happiness under a dictator". ${ }^{11}$ Support for Latin American dictators (including the regime of General Juan Vicente Gomez in Venezuela during the 1920s) soon became a staple of U.S. foreign policy toward the region, resulting in close U.S. relations with the likes of Anastasio Somoza, Fulgencio Batista, Carlos Castillo Armas, and Augusto Pinochet during the decades that followed. ${ }^{12}$ If the walls of America's white hegemony could not be held in place by U.S. troops and gunships, perhaps these brutal proxies could keep the "half-breeds" and "vicious animals" under control.

\section{Conclusions: Reinforcing the Color Line}

At the dawn of the twentieth century, W. E. B. Du Bois surveyed the world of race with very different eyes. In his "To the Nations of the World" speech, presented at the first Pan-African Conference in July 1900, he implored the white nations of the world to dismantle the racial barriers that had for so long divided humanity:

In the metropolis of the modern world, in this the closing year of the nineteenth century, there has been assembled a congress of men and women of African blood, to deliberate solemnly upon the present situation and outlook of the darker races of mankind. The problem of the twentieth century is the problem of the color line, the question as to how far differences of race-which show themselves chiefly in the color of the skin and the texture of the hair-will hereafter be made the basis of denying to over half the world the right of sharing to utmost ability the 
opportunities and privileges of modern civilization.... In any case, the modern world must remember that in this age when the ends of the world are being brought so near together the millions of black men in Africa, America and the Islands of the Sea, not to speak of the brown and yellow myriads elsewhere, are bound to have a great influence upon the world in the future, by reason of sheer numbers and physical contact" (Du Bois 1900).

By the time World War I came to a close, however, white officials and leaders in the United States had come to a very different conclusion. The "problem of the twentieth century" was not the "color line". It was, instead, the fact that the color line was under assault. At home, African Americans were more vigorously pushing for the rights they had expected since the end of the Civil War more than half a century earlier. Immigrants with different languages, religions, and skin colors were pouring across America's borders. These challenges were met with Jim Crow laws and Klan violence to stifle and intimidate the black voices, and with stringent immigration laws and notions (and policies) embracing the idea of eugenics to push back against the immigrant hordes. These reactions at home gave credence to the later portrayals of the 1920s in America as a time of reactionary isolationism, as U.S. officials and the American public turned away from international entanglements and instead put their energies and actions into "protecting" their nation from "un-American" threats. This view, however, is both misleading and instructive. Misleading because the United States hardly retreated into an isolationist shell during the post-World War I period. Indeed, it pursued its economic and political goals with surprising vigor. Yet, an examination of American racism and bigotry that dominated much of the nation's domestic politics and public discussion during the 1920s allows us to understand that those forces did not stop at the nation's shores. As Du Bois astutely noted, abroad, the power and authority of white America and Western Europe was being challenged by "the black men in Africa" and the "brown and yellow myriads elsewhere". For white U.S. officials and intellectuals, however, the idea that these hordes of people of color could "have a great influence upon the world in the future, by reason of sheer numbers and physical contact" was not a cause for celebration but instead for deep and worrisome reconsiderations of how to best contain those masses. Efforts to breach the color line, such as the Japanese race proposal at Versailles, would need to be blocked. A close eye would need to be kept on the "yellow hordes" of Asia. Simply blocking them from entrance into the United States was not enough. The pressures of the Asian masses would need to be contained in order to prevent them from pouring into Africa, Latin America, and other underdeveloped areas of the globe that were essential American economic and political goals in the postwar world. Latin America was of particular concern. The efforts of the racially suspect leaders and people of that region to secure more say in their own political and economic future was worrisome and threatened the vast network of U.S. investments and trade, as well as the necessary political stability in which those economic interests operated. In such a world, a philosophical color line was not sufficient. Sturdier barriers, in the forms of resistance to ideas of racial equality, military interventions, political and economic pressure, and reliance on oppressive dictators, would need to be constructed to survive the rising tide of color.

Funding: This research received no external funding.

Institutional Review Board Statement: Not applicable.

Informed Consent Statement: Not applicable.

Data Availability Statement: Not applicable.

Conflicts of Interest: The author declares no conflict of interest.

\section{Notes}

See Williams (1954). During the 1970s and 1980s, U.S. diplomatic historians eventually caught up to Williams and produced a series of important books on U.S. foreign relations during the 1920s (Costigliola 1984; Leffler 1979; Hogan 1977; Hoff-Wilson 1971 
were just a few of the monographs that appeared during those years). Indeed, their work served as the impetus for my own study (Krenn 1990).

2 For more on the Red Summer, see (McWhirter 2011; Krugler 2014; Whitaker 2009).

3 See Jacobson (1999). For more on the eugenics movement in the United States, see (Black 2003; Leonard 2016; Cohen 2017). For a wonderful recent study that brings together the debates over eugenics and immigration, see Okrent (2019).

4 The Crisis, January 1915, pp. 119-20. Reprinted in Katz (1967).

5 For more on the events surrounding the Japanese race proposal, see Lauren (1978), "Human Rights in History" and Shimazu (2009).

$6 \quad$ For more on U.S. relations with Latin America during the Wilson years and the 1920s, see (Krenn 1990; Gilderhus 1986; Seidel 1971; Grieb 1976; Smith 1972; Tulchin 1971). Some recent general studies of U.S. relations with Latin America also offer fascinating insights into the post-World War I relationship (Schoultz 1998; Grandin 2021; Gilderhus et al. 2017).

7 Jordan Stabler to Frank Polk, 1 and 25 March 1919, Box 12, Folder 445, Papers of Frank Polk, Yale University Library, New Haven, CT.

$8 \quad$ Henry P. Fletcher to Polk, 26 June 1918, Box 5, Folder 179, Polk Papers.

9 James R. Sheffield to Nicholas Murray Butler, 17 November 1925, Box 8, Papers of James R. Sheffield, Yale University Library; Diary of Chandler P. Anderson, "Mexican Trip. Feb. 18 to March 14" 1926, Papers of Chandler P. Anderson (microfilm), Manuscripts Division, Library of Congress, Washington, DC; Anderson Diary, 29 October 1926, Anderson Papers, LOC.

10 Minister Samuel Piles to Secretary of State Frank Kellogg, 11 June 1928; Report to Major Lester Baker, contained in William Manning to Dana Munro, 14 October 1929; C. Van H. Engert to Henry Stimson, 23 December 1929, 821.6363/410; 832.00/649; 831.00/1449, Record Group 59, General Records of the Department of State, National Archives, Washington, DC.

11 Henry Stimson, “Memorandum of Conference with Mr. Root, July 6, 1927. Re Nicaragua”, Papers of Henry L. Stimson (microfilm), Yale University Library; Root, "Speech before a dinner meeting of the Council on Foreign Relations", 14 December 1926, Records of Meetings, vol. 2, Archives of the Council on Foreign Relations, New York City, NY.

12 For some interesting discussions of the history of U.S. involvement with despotic regimes in Latin America, see (Lewis 2006; Schmitz 1999).

\section{References}

Black, Edwin. 2003. War against the Weak: Eugenics and America's Campaign to Create a Master Race. Washington, DC: Dialog Press. Cohen, Adam. 2017. Imbeciles: The Supreme Court, American Eugenics, and the Sterilization of Carrie Buck. New York: Penguin Books. Costigliola, Frank. 1984. Awkward Dominion: American Political, Economic, and Cultural Relations with Europe, 1919-1933. Ithaca: Cornell University Press.

Du Bois, William Edward Burghardt. 1900. To the Nations of the World. July 25. Available online: https://www.blackpast.org/africanamerican-history /1900-w-e-b-du-bois-nations-world/ (accessed on 8 February 2022).

Gilderhus, Mark T. 1986. Pan American Visions: Woodrow Wilson in the Western Hemisphere, 1913-1921. Tucson: University of Arizona Press.

Gilderhus, Mark T., David C. LaFevor, and Michael J. LaRosa. 2017. The Third Century: U.S.-Latin American Relations Since 1889. Lanham: Rowman \& Littlefield.

Grandin, Greg. 2021. Empire's Workshop: Latin America, the United States, and the Making of an Imperial Republic. New York: Picador.

Grant, Madison. 1936. The Passing of the Great Race; or, The Racial Basis of European History, 4th ed. New York: Charles Scribner's Sons, pp. 79-80.

Grieb, Kenneth J. 1976. The Latin American Policy of Warren G. Harding. Fort Worth: Texas Christian University Press.

Hoff-Wilson, Joan. 1971. American Business and Foreign Policy, 1920-1933. Lexington: University of Kentucky Press.

Hogan, Michael. 1977. Informal Entente: The Private Structure of Cooperation in Anglo-American Economic Diplomacy, 1918-1928. Columbia: University of Missouri Press.

Jacobson, Matthew Frye. 1999. Whiteness of a Different Color: European Immigrants and the Alchemy of Race. Cambridge: Harvard University Press, pp. 82-83.

Katz, William Loren. 1967. Eyewitness: The Negro in American History. New York: Pitman Publishing Corporation, pp. 389-90.

Krenn, Michael L. 1990. U.S. Policy toward Economic Nationalism in Latin America, 1917-1929. Wilmington: Scholarly Resources, Inc.

Krugler, David F. 2014. 1919, the Year of Racial Violence: How African Americans Fought Back. Cambridge: Cambridge University Press.

Lauren, Paul Gordon. 1978. Human Rights in History: Diplomacy and Racial Equality at the Paris Peace Conference. Diplomatic History 2: 257-58. [CrossRef]

Leffler, Melvyn. 1979. The Elusive Quest: America's Pursuit of European Stability and French Security, 1919-1933. Chapel Hill: University of North Carolina Press.

Leonard, Thomas C. 2016. Illiberal Reformers: Race, Eugenics \& American Economics in the Progressive Era. Princeton: Princeton University Press. 
Lewis, Paul H. 2006. Authoritarian Regimes in Latin America: Dictators, Despots, and Tyrants. New York: Rowman \& Littlefield Publishers. McWhirter, Cameron. 2011. Red Summer: The Summer of 1919 and the Awakening of Black America. New York: Henry Holt and Co.

Office of the Historian, U.S. Department of State. 2021. A Short History of the Department of State: A Return to Isolationism. Available online: https: / / history.state.gov/departmenthistory/short-history/return (accessed on 12 July 2021).

Okrent, Daniel. 2019. The Guarded Gate: Bigotry, Eugenics, and the Law That Kept Two Generations of Jews, Italians, and Other European Immigrants Out of America. New York: Scribner.

Schmitz, David F. 1999. Thank God They're on Our Side: The United States and Right-Wing Dictatorships, 1921-1965. Chapel Hill: University of North Carolina Press.

Schoultz, Lars. 1998. Beneath the United States: A History of U.S. Policy Toward Latin America. Cambridge: Harvard University Press.

Seidel, Robert Neal. 1971. Progressive Pan Americanism: Development and United States Policy toward South America, 1916-1932. Ithaca: Cornell University Press.

Shimazu, Naoko. 2009. Japan, Race and Equality: The Racial Equality Proposal of 1919. New York: Routledge.

Smith, Robert Freeman. 1972. The United States and Revolutionary Nationalism in Mexico, 1916-1932. Chicago: University of Chicago Press.

Stoddard, Lothrop. 1921. The Rising Tide of Color: The Threat against White World Supremacy. New York: Charles Scribner's Sons, pp. 7-9, $48-49,231-32$

Tulchin, Joseph. 1971. The Aftermath of War: World War I and U.S. Policy toward Latin America. New York: New York University Press.

Whitaker, Robert. 2009. On the Laps of Gods: The Red Summer of 1919 and the Struggle for Justice that Remade a Nation. New York: Crown Publishing Group.

Williams, William Appleman. 1954. The Legend of Isolationism in the 1920's. Science E Society 18: 1-20. 